УДК 378.4

DOI https://doi.org/10.32837/apfs.v0i32.1033

О.Ю.Рилова

ORCID ID: https://orcid.org/0000-0002-1735-613X аспірантка, викладач кафедри філософських і політичних наук Черкаського державного технологічного університету

\title{
СВІТОВІ ТЕНДЕНЦІЇ РОЗВИТКУ ВИЩОЇ ОСВІТИ ТА ІІЇ ЯКІСТЬ
}

Постановка проблеми. Стрімкі соціальноекономічні, політичні, технологічні та культурні перетворення, які відбуваються у світі протягом останніх п’ятдесяти років, значною мірою стосуються сфери вищої освіти. Відповіддю на налагодження міжнародних зав'язків, відкриті кордони та політику егалітаризму стають уніфікація національних систем вищої освіти, їх інтернаціоналізація та створення єдиного освітнього простору; посилення конкуренції між університетами та зменшення державного фінансування; диверсифікація закладів вищої освіти та розширення доступу для людей, які є представниками різних соціальних класів, націй та вікових груп. Ці тенденції можна розглядати як підстави для посилення уваги до якості вищої освіти.

Аналіз останніх досліджень і публікацій. Сучасні зарубіжні та українські науковці виділяють різноманітні тенденції розвитку вищої освіти. Зокрема, проблемі глобалізації вищої освіти присвятили свої роботи Г. Нів, Е. Гідденс, С. Мачин, P. Мерфi, А. Бойко, В. Бурачек, О. Василенко, 0. Ісаєва. Маркетизацію вищої освіти досліджують С. Маргінсон, С. Янг, Д. Ділл, О. Жегус, Н. Савицька, Н. Волосова. Масовізація вищої освіти стала предметом наукових пошуків М. Троу, Е. Тоффлера, П. Скотта, Ф. Альтбаха, С. Щудло, Л. Хижняк, С. Курбатова, П. Сауха.

Різним аспектам феномена якості вищої освіти та проблемі її забезпечення в сучасному науковому дискурсі приділяють увагу Р. Дікер, М. Гомес, Л. Шиндлер, С. Квіт, С. Ніколаєнко, В. Мороз, Я. Тицька, О. Пономарьов.

Метою статті є аналіз сучасних тенденції розвитку вищої освіти та представлення основних концепцій щодо якості вищої освіти.

Виклад основного матеріалу. На початку XXI століття у більшості країн світу вища освіта перетворилась на один із провідних соціальних інститутів, на який покладається дуже важлива місія. 3 одного боку, поява так званої економіки знань та демократизація галузі визначають її стратегічну роль у досягненні прогресу та підтримці конкурентоспроможності країни загалом. 3 іншого боку, глибокі технологічні, наукові, політичні, соціальні й культурні трансформації, які відбуваються у світі, потребують динамічних навчальних та наукових установ, здатних переосмислити систему підготовки фахівців, а також основні напрями проведення наукових досліджень 3 урахуванням вимог часу.

У зв'язку з цим професор Оксфордського університету, директор Центру глобальної вищої освіти, головний редактор журналу «Вища освіта» Саймон Маргінсон виділяє три взаємопов'язані світові тенденції розвитку вищої освіти, які сформувалися протягом останніх двадцяти років. Це, по-перше, глобалізація, або глобальна конвергенція та інтеграція національних систем; по-друге, маркетизація, або посилення конкуренції між установами; по-трете, масовізація, або масове розширення систем вищої освіти [9].

Вивчаючи глобалізацію, британський соціолог, директор із досліджень Центру досліджень політики вищої освіти (CIPES) Гай Нів визначив iї як «прискорений обмін», що передбачає як економічні, так і культурні аспекти [13, с. 332]. Внаслідок розширення обміну товарами і продуктами, культурними цінностями та знаннями світ стає все більш взаємопов' язаним та схожим на єдине «співтовариство», уникнути чого неможливо, про що майже шістдесят років тому писав канадський філософ та культуролог Маршал Маклюен [5, с. 103].

Директор Лондонської школи економіки та політичних наук Ентоні Гідденс, дискутуючи про глобалізацію, констатує, що в основі економічних і культурних трансформацій лежать комунікація та обмін інформацією [10]. Таким чином, можна стверджувати, що технологічні умови для створення першого світового співтовариства забезпечила поява Інтернету у 90 -х роках XX століття.

Вища освіта не стоїть осторонь процесу глобалізації. Сьогодні спостерігається феноменальне зростання мобільності викладачів та студентів, створюються транскордонні консорціуми між закладами вищої освіти, розширюється обмін інформацією та передовим досвідом. Світ стає свідком зародження, швидкого зростання та диверсифікації вищої освіти на глобальному рівні, що супроводжується збільшенням обсягу знань, якими володіє людство. Саймон Маргінсон звертає увагу на те, що в сучасному світі чверть усіх наукових робіт створюється завдяки колегіальній співпраці науковців із різних країн. Більш того, на його думку, саме отримання вищої освіти та здобуття знань є найбільш глобалізованими видами 
людської діяльності. Під глобалізацією дослідник перш за все розуміє тенденцію до всезагального зближення у сфері вищої освіти і наукових досліджень. Він вважає, що глобалізація має величезний потенціал, адже спільні дії дають можливість вийти за національні межі. Оскільки жодна країна або культура не має відповідей на всі питання, їм є чому повчитися одна у одної, то глобалізація повинна сприяти зближенню різноманітних людських ідей, знань, уявлень тощо.

3 часом усе глибше занурюючись у глобальні процеси, вища освіта суттєво трансформується. 3 моменту формулювання німецьким дослідником Вільгельмом фон Гумбольдтом ідеї класичного університету на початку XIX століття, створенням закладів вищої освіти, регулюванням їхньої діяльності та фінансуванням опікувалася держава. Весь цей час ринок впливав на ці взаємовідносини опосередковано, лише як потенційний роботодавець для випускників. Однак з огляду на глобальні культурні, соціальні, економічні та політичні перетворення, які відбулися протягом останніх п'ятдесяти років, ситуація суттєво змінилася: «державна» освіта стала «ринковою», тобто відбулася її маркетизація.

Як правило, маркетизацію вищої освіти пов' язують із поширенням на неї засад функціонування ринку, зокрема таких, як зменшення державного регулювання, посилення конкуренції та пошук додаткових джерел фінансування.

Дуже важливу роль у процесі маркетизації вищої освіти відіграє інституційна автономія, адже без неї в сучасному світі заклади вищої освіти не можуть повноцінно реалізовувати свою місію та отримувати вигоду від своєї діяльності. «Виживання» освітніх установ залежить від їхньої здатності підтримувати та збільшувати свою присутність на ринку, отже, кожна з них прагне залучити якомога більше студентів та кращих викладачів. Зростає необхідність підтримання зв'язків із громадськістю та просування як на місцевому, так і на міжнародному рівнях. Крім того, посилення конкуренції змушує заклади вищої освіти проводити «маркетингову розвідку» та проявляти підвищену увагу до інформації, яка про них поширюється.

В умовах ринку університети не мають змоги ефективно працювати без адекватного фінансування. Заклади вищої освіти по всьому світі мають різний досвід, як вдалий, так і не дуже, стосовно джерел, обсягів та механізмів фінансової підтримки. Коли йдеться про додаткові джерела, то до них зазвичай належать внески, що сплачують безпосередньо самі студенти або члени їхніх сімей, кошти юридичних осіб, різноманітні позики, кошти, сплачені за додаткові освітні послуги, пожертви випускників чи інших осіб, фінансування від міжнародних організацій.
В сучасному світі більшість національних систем вищої освіти входить до складу глобальної системи та світових рейтингів, хоча одні з них більш активно включаються у процес конвергенції, ніж інші. В багатьох країнах через маркетизацію віщої освіти спостерігаються послаблення державного впливу в межах галузі, зростання конкуренції та зміна механізмів фінансування. Проте майже всі національні системи вищої освіти протягом останніх десятиліть переживають стійке та динамічне зростання або зазнають суттєвого розширення, тому 3 трьох тенденцій, які виділив Саймон Маргінсон, найбільш універсальною можна вважати саме масовізацію.

У 1973 році американський соціолог Мартін Троу представив свою модель розвитку вищої освіти, згідно з якою відбувався перехід від «елітної» системи, яка охоплювала менше 15\% молоді, до «масової» із залученням від $15 \%$ до $50 \%$ випускників шкіл, а потім і до «універсальної» системи, в межах якої вища освіта стає загальною необхідністю і її здобуває понад 50\% представників відповідної вікової групи [15]. Крім того, дослідник припустив, що в майбутньому всі розвинені країни будуть рухатися до масової участі у вищій освіті, і він мав рацію.

Розпочавшись із країн Північної Америки та Західної Європи, масовізація вищої освіти поступово поширилась на Азію, Латинську Америку та Східну Європу. Якщо на початку 70-х років ХХ століття тільки 19 країн перетнули межу «масової» вищої освіти у 15\%, то у 2013 році у світі нараховувалося вже більше 110 таких систем та 56 систем, де рівень охоплення становив понад $50 \%$. Водночас решта країн усе ще не змогла подолати позначку у 15\% [17]. Найбільше зростання кількості студентів відбулося за останні двадцять років. За даними ЮНЕСКО, кожного року участь у вищій освіті зростає на 1 відсоток [16].

Сьогодні третина світових систем вищої освіти зараховує на навчання понад $50 \%$ молоді, яка здобула середню освіту. За інформацією сайту Державної служби статистки України, у 2020 році кількість учнів, які одержали атестат про здобуття повної загальної середньої освіти, становила 222277 осіб, а кількість осіб, що вперше вступили до закладів вищої освіти (університети, академії, інститути), без тих, хто продовжує навчання задля здобуття більш високого освітнього рівня за скороченими програмами, сягнула 277057 осіб [3], тобто коефіцієнт зарахування склав понад $124,6 \%$ і перевершив навіть показники «універсальних» систем вищої освіти за класифікацією М. Троу. Звичайно, ці величини є відносними, але вони свідчать про стійкий масовий попит на вищу освіту в нашій країни.

Глобалізація, маркетизація та масовізація вищої освіти спричинили посилення уваги до 
проблеми її якості. Щоби мати змогу повноцінно реалізувати свою місію, сучасні заклади вищої освіти повинні відповідати певним стандартам, які можуть стосуватися як установи загалом, такі і освітніх програм зокрема.

Якість вищої освіти, як правило, знаходить відображення у професіоналізмі випускників, їхніх вміннях і навичках, а також в актуальності та рівні знань, що виробляються в ході проведення досліджень, адже, якщо, наприклад, випускники не здатні ефективно виконувати свою роботу через низьку якість знань, отриманих у закладі освіти, можна однозначно стверджувати, що він не реалізовує свою місію.

Слід наголосити на тому, що часто під час різноманітних дискусій фундаментальне питання «Що таке якість вищої освіти?» просто опускається. Швидше за все, це пов'язано, з одного боку, з тим, що відповідь на нього є неоднозначною, а єдиного остаточного визначення цього поняття немає, а з іншого боку, з тим, що забезпечення якості вищої освіти є складним, динамічним процесом. У жовтні 2011 року колишній директор та проректор Університету Роберта Гордона в Абердині (Шотландія) Фердінанд фон Прондзінскі у своєму блозі «Щоденник життя та стратегія всередині і поза університетом» писав таке: «Ймовірно, буде нескладно прийти до консенсусу щодо того, що університети мають прагнути високої якості як свого навчання, так і своїх досліджень. Однак значно складніше визначити, що таке якість насправді» [14].

Доцент Інституту освітніх досліджень Університету Аддіс-Абеби (Ефіопія) Мулу Нега Кахсай у 2012 році провів комплексний аналіз літератури, присвяченої проблемі якості вищої освіти, i також дійшов висновку про відсутність чіткого визначення цього поняття. Замість того, щоби спробувати однозначно визначити якість, експерти в галузі вищої освіти застосовують різноманітні описові конструкції. Наприклад, якість як вища міра, досконалість; якість як відповідність меті; якість як підвищення ефективності. Деякі дослідники, намагаючись пояснити, що таке якість вищої освіти, розглядають ії в контексті набору студентів, змісту освітніх програм, використання сучасних технологій викладання, наявних ресурсів тощо. Популярною е ідея трактування якості вищої освіти з точки зору зацікавлених сторін, кожна з яких, на думку прихильників такого підходу, має свої уявлення про якість. Наприклад, студенти та їхні батьки перш за все будуть звертати увагу на умови навчання та сучасні підходи до викладання; роботодавці - на практичні вміння та навички випускників; науковці - на взаємозв'язок викладання та досліджень; політики - на ефективність роботи закладів вищої освіти. М.Н. Кахсай вважає, що врахування думок, які часто кардинально відрізняються одна від одної, не може стати ключем до визначення якості вищої освіти [11].

Також існуе думка про те, що якість вищої освіти слід розглядати з позиції соціальної відповідальності, коли результати досліджень та навчання студентів сприймаються як інструмент позитивних перетворень, що забезпечує підвищення соціального статусу та стимулює зростання загального добробуту як на рівні окремої людини, так і на рівні суспільства загалом [8].

Якість завжди була частиною академічної традиції, але раніше вона здебільшого спиралась на саморегулювання та неформальні огляди експертів. В. фон Гумбольдт зазначав, що «держава має повсякчас усвідомлювати, що прямий вплив з їі боку неприпустимий» [2, с. 26]. Сьогодні ж ситуація кардинально змінилася. За останні кілька десятиліть забезпечення якості вищої освіти перетворилось на надзвичайно складний, динамічний процес, проте розвинені країни вже мають успішний досвід його практичної реалізації. Іншим же країнам слід пам'ятати про те, що «імпорт» моделей забезпечення якості вищої освіти без належної адаптації до місцевих умов та розуміння потреб населення навряд чи у перспективі буде успішним та приведе до позитивних змін.

Як правило, процес забезпечення якості вищої освіти передбачає такі процедури, як контроль, оцінювання, вимірювання, підвищення рівня та підзвітність. Для їх реалізації у багатьох країнах світу створюються національні агентства із забезпечення якості вищої освіти, розробляються формальні стандарти якості та здійснюються спеціальні процедури перевірки (наприклад, акредитація) як на рівні закладів вищої освіти загалом, так і на рівні освітніх програм зокрема, а іноді на обох рівнях разом.

Законом України «Про вищу освіту» від 2014 року було передбачено створення Національного агентства із забезпечення якості вищої освіти (НАЗЯВО), яке має стати рушійною силою забезпечення якості вищої освіти в нашій державі. Проте з низки причин цей орган запрацював лише наприкінці лютого 2019 року. Як зазначено на офіційному сайті, серед іншого НАЗЯВО покликаний гарантувати якість освітніх програм через впровадження ефективної процедури їх акредитації, погоджувати стандарти та розробляти критерії забезпечення якості вищої освіти на основі передових світових і національних практик [6].

Діяльність подібних установ можна віднести до так званого зовнішнього, або системного, рівня забезпечення якості. Однак, як виявилося, таких формальних механізмів недостатньо для стимулювання значного покращення та трансформації якості на рівні закладів вищої освіти. Більш 
того, наявність формальних вимог і процедур приводить лише до посилення бюрократизації галузі та додаткової «паперової» роботи. Отже, у процесі забезпечення якості вищої освіти важлива роль відводиться внутрішньому рівню, на якому ключовими відповідальними агентами та експертами повинні виступити заклади вищої освіти, адже вони справляють безпосередній вплив на реальну якість викладання та навчання і здатні забезпечити іï покращення. Такий підхід був схвалений на міжнародному рівні, і до законодавчих актів багатьох країн внесли відповідні зміни.

Висновки. Проблематика, розглянута у статті, являє собою лише деякі з найбільш поширених ідей, пов'язаних з основними тенденціями розвитку вищої освіти та проблемами забезпечення ïï якості, що відображені в науковій літературі.

Однією з ключових тенденцій розвитку вищої освіти у XXI столітті є їі глобалізація, тобто зближення національних систем на міжнародному рівні, їх інтернаціоналізація та формування єдиного освітнього простору. Це, безумовно, приводить до маркетизації вищої освіти, що проявляється у посиленні конкуренції між університетами, які прагнуть залучити більшу кількість студентів та кращих дослідників, щоб отримати додаткові бали до своїх рейтингів. Уряди країн надають закладам вищої освіти все більше свободи та змінюють механізми їх фінансування. Ці трансформації відбуваються на фоні масовізації та розширення доступу до вищої освіти для всіх верств населення.

Зазначені тенденції приводять до серйозних змін у структурі та сфері управління закладами вищої освіти, перегляду змісту освітніх програм та навчальних планів i, найголовніше, до посилення уваги до якості вищої освіти. Актуальною проблемою залишається відсутність однозначного визначення якості вищої освіти та чітких критеріїв її забезпечення. Задля цього у різних країнах світу, в тому числі в Україні, створюються національні агентства забезпечення якості вищої освіти, які здійснюють контроль та оцінювання рівня якості, а також та стимулюють його підвищення.

Деякі країни розглядають зазначені тенденції як загрозу для розвитку національних систем вищої освіти, однак більшість все ж таки вважає їх умовами для проведення масштабних реформ задля позитивних перетворень та адаптації до нових умов.

\section{Jimepamypa}

1. Ахновська I. Управління рівнем дивергенції та конвергенції в освіті. Еконоліка $і$ організаціл управління. 2018. № 2 (30). С. 14-21.

2. Гумбольдт В. фон. Про внутрішню та зовнішню організацію вищих наукових закладів у Берліні. Ідея
Університету : антологія / упоряд.: М. Зубрицька, Н. Бабалик, 3. Рибчинська ; відп. ред. М. Зубрицька. Львів : Літопис, 2002. С. 23-33.

3. Державна служба статистки України : вебсайт. URL: http://www.ukrstat.gov.ua (дата звернення: 22.11.2021).

4. Жегус О. Вищий навчальний заклад в умовах маркетизації сфери вищої освіти. Економічний проcmip. 2017. № 122. C. 193-204.

5. Маклюэн Г.М. Понимание Медиа: Внешние расширения человека / пер. с англ. В. Николаева. Москва : КАНОН-пресс-Ц ; Жуковский : Кучково поле, 2003. 464 с.

6. Національне агентство із забезпечення якості вищої освіти : вебсайт. URL: https://naqa.gov.ua (дата звернення: 22.11.2021).

7. Річний звіт Національного агентства із забезпечення якості вищої освіти / за заг. ред. С. Квіта, О. Сременко. Київ : Національне агентство із забезпечення якості вищої освіти, 2021. $364 \mathrm{c.}$

8. Biggs J. The reflective institution: Assuring and enhancing the quality of teaching and learning. Higher Education. 2001. № 41. P. 221-238. URL: https://www.researchgate.net/publication/44830072_ The_reflective_institution_Assuring_and_enhancing_ the_quality_of_teaching_and_learning (дата звернення: 22.11.2021).

9. Cantwell B., Marginson S., Smolentseva A. High Participation Systems of Higher Education. DOI: $10.1093 /$ oso/9780198828877.001.0001.

10. Giddens A. The Great Globalization Debate : The Zellerbach Distinguished Lecture. University of California, Berkeley. 25 October 2001. URL: https://carnegieendowment.org/2000/07/05/anthony-giddens-discusses-globalization-debate-pub-8655 (дата звернення: 22.11.2021).

11. Kahsay M.N. Quality and Quality Assurance in Ethiopian Higher Education: Critical Issues and Practical Implications. Center for Higher Education Policy Studies (CHEPS). URL: https://research.utwente.nl/en/ publications/quality-and-quality-assurance-in-ethiopian-higher-education-criti (дата звернення: 22.11.2021).

12. Marginson S. Education and the Trend to Markets. Australian Journal of Education. 1999. Vol. 43. P. 229-240. DOI: 10.1177/000494419904300302.

13. Neave G. Academic freedom in an age of globalization. Higher Education Policy. 2002. Vol. 15. P. 331-335. DOI: 10.1016/S0952-8733(02)00053-3.

14. Prondzynski F. von. Diary of life and strategy inside and outside the university : A University Blog. URL: https://universitydiary.wordpress.com/2011/10/ page/2 (дата звернення: 22.11.2021).

15. Trow M.A. Problems in the transition from elite to mass higher education. 1973. 57 p. URL: https://eric. ed.gov/?id=ED091983 (дата звернення: 22.11.2021).

16. UNESCO Institute for Statistics. URL: http:// data.uis.unesco.org (дата звернення: 22.11.2021).

17. World Bank Open Data. URL: https://data. worldbank.org (дата звернення: 22.11.2021). 


\section{Анотація}

Рилова О. Ю. Світові тенденції розвитку вищої освіти та їі якість. - Стаття.

У статті акцентовано увагу на тому, що стрімкі соціально-економічні, політичні, технологічні та культурні перетворення, які сьогодні відбуваються у світі, значною мірою стосуються сфери вищої освіти. Розглянуто основні тенденції розвитку вищої освіти, які сформувалися протягом останніх двадцяти років. Зокрема, йдеться про глобалізацію, або конвергенцію та інтеграцію національних систем, маркетизацію, або посилення конкуренції між установами, та масовізацію, або диверсифікацію галузі та розширення доступу до вищої освіти для широких верств населення незалежно від національності, віку, соціального статусу. Зазначено, що всі ці процеси ведуть до формування єдиного освітнього простору шляхом уніфікації окремих систем вищої освіти та нівелювання їхніх відмітних ознак і запровадження стандартів. Наголошено на серйозних змінах у структурі та сфері управління закладами вищої освіти, перегляді змісту освітніх програм та навчальних планів, зменшенні державного регулювання та нових механізмах фінансування. Прослідковано зв'язок між ключовими тенденціями розвитку вищої освіти у XXI столітті та посиленням уваги до проблеми її якості. Підкреслено, що серйозним викликом залишається відсутність однозначного визначення поняття якості вищої освіти та чітких критеріїв її забезпечення. Проаналізовано основні підходи до тлумачення поняття якості вищої освіти, представлені в науковій літературі. Констатовано, що забезпечення якості вищої освіти $\epsilon$ складним динамічним процесом, який передбачає такі процедури, як контроль, оцінювання, вимірювання, підвищення рівня та звітність. Задля цього у багатьох країнах світу, в тому числі в Україні, створюються національні агентства із забезпечення якості вищої освіти, розробляються формальні стандарти якості та здійснюються спеціальні процедури перевірки як на рівні закладів вищої освіти загалом, так і на рівні освітніх програм зокрема, а іноді на обох рівнях разом.

Ключові слова: тенденції розвитку вищої освіти, глобалізація вищої освіти, маркетизація вищої освіти, масовізація вищої освіти, якість вищої освіти.

\section{Summary}

Rylova $O$. Yu. The worldwide higher education trends and quality in higher education. - Article.

The article presented by the author focuses attention on the rapid socio-economic, political, technological and cultural transformations that are taking place in the modern world, and largely relate to the field of higher education. Considers the main worldwide higher education trends that have formed during the past twenty years. These include globalization, or convergence and integration between national systems; marketization, or intensification of competition between institutions; and massification, or diversification of the industry and expanding access to higher education for broad sector of the population, regardless of age, social status, etc. It is noted that all these processes lead to the setting up of single higher education area through unite a large number of individual systems and unifies them by leveling out distinctive features and lowering standards. The article emphasizes the significant transformations in the structure and management of higher education institutions, revision of the content of academic programs and curricula, reduction of state regulation and new funding mechanisms. The connection between the key higher education trends in the XXI century and greater focus on quality in higher education is traced. The author underline that the answer for the question "What is quality in higher education?" became the serious challenge. There is no unified definition or single measure for quality in higher education. The main attempting to explain and systematize the concept of quality in higher education presented in the scientific literature are analyzed. At the same time, it is shown that quality assurance in higher education is a complex dynamic process, which includes such procedures as such as control, evaluation, measurement, quality improvement and accountability. To this aim, in many countries, including Ukraine, national agencies quality assurance in higher education are opened, formal quality standards are implemented and specific review procedures at the level of higher education institutions or at the level of academic programs, or both.

Key words: higher education trends, globalization of higher education, marketization of higher education, massification of higher education, quality in higher education. 